\title{
Increased Calcium Intake Does Not Suppress Circulating 1,25-Dihydroxyvitamin D in Normocalcemic Patients with Sarcoidosis
}

\author{
Jan N. Basile, Yair Liel, Judith Shary, and Norman H. Bell \\ Department of Medicine, Medical University of South Carolina, Charleston, South Carolina 29425, and the Ralph H. Johnson \\ Department of Veterans Affairs Medical Center, Charleston, South Carolina 29401-5799
}

\begin{abstract}
Ca absorption is regulated by $1,25(\mathrm{OH})_{2} \mathrm{D}$, and serum values vary inversely with $\mathrm{Ca}$ intake. In sarcoidosis, $1,25(\mathrm{OH})_{2} \mathrm{D}$ is produced by alveolar macrophages in response to $\boldsymbol{\gamma}$-interferon, and patients may develop hypercalcemia after prolonged exposure to sunlight and increased dermal production of vitamin $D_{3}$. To determine if increased $\mathrm{Ca}$ intake suppresses serum $1,25(\mathrm{OH})_{2} \mathrm{D}$ in normocalcemic patients and to identify those at risk, 17 normal subjects and 11 patients were studied on a metabolic ward for two and one-half days while receiving first 400 and then $1,000 \mathrm{mg} / \mathrm{d}$ of $\mathrm{Ca}$. On the low $\mathrm{Ca}$ intake, serum angiotensin-converting enzyme ( $\mathrm{ACE}$ ), an index of disease activity, was higher in only three of the patients than in the controls, mean serum $1,25(\mathrm{OH})_{2} \mathrm{D}$ was higher in the patients, and mean serum total $\mathrm{Ca}$, serum $\mathrm{Ca}^{++}$, and urinary $\mathrm{Ca}$ were not different in the two groups. On the higher $\mathrm{Ca}$ intake, mean urinary $\mathrm{Ca}$ increased in both groups, but mean serum $1,25(\mathrm{OH})_{2} \mathrm{D}$ was suppressed only in the normal subjects. Thus, $1,25(\mathrm{OH})_{2} \mathrm{D}$ production is abnormally regulated, indicating that $(a)$ normocalcemic patients with sarcoidosis are at risk for developing abnormal Ca metabolism, and $(b)$ a better index of disease activity is provided by the oral Ca suppression test than by serum ACE. (J. Clin. Invest. 1993. 91:13961398.) Key words: sarcoidosis • calcium $\bullet 1,25$-dihydroxyvitamin D • 25-hydroxyvitamin D • angiotensin-converting enzyme
\end{abstract}

\section{Introduction}

Circulating $1,25(\mathrm{OH})_{2} \mathrm{D}$ is the major determinant of intestinal absorption of calcium $(1,2)$. Values are increased when calcium intake is low and are reduced when calcium intake is high $(1,2) \cdot 1,25(\mathrm{OH})_{2} \mathrm{D}$ binds to its receptors in intestinal mucosa to enhance the transport of calcium (3). Renal production of the metabolite is closely regulated by $\operatorname{PTH}(4,5)$, calcium $(6)$, and phosphate $(7,8)$ so that, even in vitamin $D$ intoxication, hypercalcemia and abnormal calcium metabolism are caused by elevation of serum 25 -hydroxyvitamin $\mathrm{D}[25(\mathrm{OH}) \mathrm{D}]^{1}$ and

Address correspondence and reprint requests to Dr. Norman H. Bell, Ralph H. Johnson Department of Veterans Affairs Medical Center, 109 Bee Street, Charleston, SC 29401-5799.

Presented in part at the annual meeting of the American Society for Bone and Mineral Research, New Orleans, LA, 4-7 June 1988. ( 1988. J. Bone Miner. Res. 3:S114.)

Received for publication 29 June 1992 and in revised form 1 October 1992.

1. Abbreviations used in this paper: ACE, angiotensin-converting enzyme; 25(OH)D, 25-hydroxyvitamin D.

The Journal of Clinical Investigation, Inc.

Volume 91, April 1993, 1396-1398 not $1,25(\mathrm{OH})_{2} \mathrm{D}(9)$. Abnormal calcium metabolism in sarcoidosis results from increased circulating $1,25(\mathrm{OH})_{2} \mathrm{D}$ that is produced by alveolar macrophages and probably by other cells in the granuloma (10-12).

We demonstrated previously that administration of small doses of vitamin $\mathrm{D}, 10,000 \mathrm{U} / \mathrm{d}$ for $12 \mathrm{~d}$, to normocalcemic patients with sarcoidosis and no history of abnormal calcium metabolism increased serum $1,25(\mathrm{OH})_{2} \mathrm{D}$ and urinary calcium in each of them (13) and that administration of larger doses of vitamin $\mathrm{D}, 100,000 \mathrm{U} / \mathrm{d}$ for $4 \mathrm{~d}$, to normocalcemic patients without a history of abnormal calcium metabolism increased serum $1,25(\mathrm{OH})_{2} \mathrm{D}$ and serum calcium in each of them (14). In contrast, mean serum calcium and mean serum $1,25(\mathrm{OH})_{2} \mathrm{D}$ did not change in the normal subjects. These studies indicate that production of $1,25(\mathrm{OH})_{2} \mathrm{D}$ in sarcoidosis is not normally regulated, even in patients with a normal serum calcium.

In view of these findings, an investigation was performed in normal subjects and normocalcemic patients with sarcoidosis to identify those at risk for developing abnormal vitamin $\mathrm{D}$ and calcium metabolism. The utility of serum ACE to indicate activity of the disease also was investigated $(15,16)$.

\section{Methods}

17 normal subjects, 10 men and 7 women, and 11 patients with sarcoidosis, 5 men and 6 women, were admitted to the General Clinical Research Center of the Medical University of South Carolina for $2.5 \mathrm{~d}$. They ranged in age from 20 to $48 \mathrm{yr}$. The diagnosis of sarcoidosis was confirmed histologically in each of the patients. All of them were given a daily diet containing $400 \mathrm{mg}$ of calcium and $900 \mathrm{mg}$ of phosphate. Fasting blood samples were obtained for measurement of serum calcium (17), $\mathrm{Ca}^{++}$, inorganic phosphate (18), ACE, 25( $\left.\mathrm{OH}\right) \mathrm{D}(19,20)$ and $1,25(\mathrm{OH})_{2} \mathrm{D}(20)$ and two consecutive 24-h urine samples were obtained for measurement of calcium (17) and inorganic phosphate (18). Urinary creatinine (21) was determined to ensure that urine collections were complete. Both the normal subjects and patients were readmitted for a second study after they had been given elemental calcium (calcium carbonate), $200 \mathrm{mg}$ by mouth 3 times a day for 1 week (22). The added calcium was continued during the second study. Statistical analyses were carried out with Student's paired and unpaired $t$ tests.

\section{Results}

There were eight black and three white patients (Table I). The diagnosis in each of them was established by biopsy. None of them had had hypercalcemia, serum calcium and serum $\mathrm{Ca}^{++}$ were normal in all of them, and urinary calcium was increased in two of them. Serum ACE was elevated in three patients, but serum $1,25(\mathrm{OH})_{2} \mathrm{D}$ was elevated in only one patient. As judged by clinical findings-the presence of skin lesions, uveitis, dyspnea, easy fatigue, abnormal liver function tests, ele- 
Table I. Clinical Findings in Patients with Sarcoidosis

\begin{tabular}{|c|c|c|c|c|c|c|c|c|c|}
\hline Patient & Age & Sex & Race & $\begin{array}{c}\text { Serum } \\
\text { calcium }\end{array}$ & $\underset{1,25(\mathrm{OH})_{2} \mathrm{D}}{\text { Serum }}$ & $\begin{array}{l}\text { Serum } \\
\text { ACE }\end{array}$ & $\begin{array}{l}\text { Urinary } \\
\text { calcium }\end{array}$ & Biopsy & Hypercalcemia* \\
\hline & $y r$ & & & $m g / d l$ & $p g / m l$ & $U$ & $m g / d$ & & \\
\hline A & 29 & $\mathbf{M}$ & B & 9.4 & 31 & 33 & 115 & + & - \\
\hline B & 35 & $\mathbf{M}$ & B & 9.4 & 39 & 29 & 169 & + & - \\
\hline $\mathrm{C}^{\ddagger}$ & 38 & $F$ & B & 9.0 & 38 & 68 & 201 & + & - \\
\hline D & 39 & $\mathbf{M}$ & B & 9.4 & 28 & 22 & 122 & + & - \\
\hline E & 31 & $F$ & B & 9.4 & 64 & 68 & 78 & + & - \\
\hline$F$ & 26 & $F$ & W & 8.7 & 44 & 30 & 188 & + & - \\
\hline G & 22 & $\mathbf{M}$ & B & 9.0 & 42 & 28 & 20 & + & - \\
\hline $\mathbf{H}$ & 39 & $F$ & W & 8.7 & 44 & 29 & 313 & + & - \\
\hline $\mathbf{I}^{\ddagger}$ & 48 & $F$ & B & 9.5 & 39 & 35 & 244 & + & - \\
\hline $\mathbf{J}$ & 48 & $\mathbf{M}$ & W & 9.3 & 22 & 19 & 225 & + & - \\
\hline K & 35 & $\mathbf{M}$ & B & 9.4 & 41 & 54 & 79 & + & - \\
\hline
\end{tabular}

* By history.

₹ Subsequently developed hypercalcemia.

Urine values are the mean of two consecutive 24-h collections.

vated serum ACE or abnormal chest $\mathrm{x}$-ray-all of the patients except one had active disease. One patient eventually died of pulmonary insufficiency caused by sarcoidosis.

In control studies, mean serum ACE was significantly 1 higher, mean serum $25(\mathrm{OH}) \mathrm{D}$ was significantly lower in the patients than in the normal subjects, and mean serum calcium, serum $\mathrm{Ca}^{++}$and phosphate and urinary calcium were not different in the two groups (Table II). Mean urinary phosphate was significantly higher in the normal subjects than in the patients.

Increasing the calcium intake from 400 to $1,000 \mathrm{mg} / \mathrm{d}$ significantly increased mean urinary calcium by $44 \%$, lowered mean urinary phosphate in the normal subjects, and signifcantly increased mean urinary calcium by $50 \%$ in the patients (Table II). Mean serum calcium, serum $\mathrm{Ca}^{++}$, and serum $25(\mathrm{OH}) \mathrm{D}$ did not change in either the normal subjects or patients. Mean serum phosphate increased modestly in the normal subjects in response to the calcium, but did not change in the patients. The increased calcium intake significantly lowered mean serum $1,25(\mathrm{OH})_{2} \mathrm{D}$ in the normal subjects but not in the patients (Table II, Figure 1).

\section{Discussion}

As noted already, we found that administration of modest doses of vitamin D to normocalcemic patients either with or without a history of hypercalcemia produced increases in serum $1,25(\mathrm{OH})_{2} \mathrm{D}$ and abnormal calcium metabolism in each of them $(13,14)$. The present findings showing failure of increased calcium intake to diminish serum $1,25(\mathrm{OH})_{2} \mathrm{D}$ in another group of normocalcemic patients with sarcoidosis who had no history of hypercalcemia provide evidence for abnormal vitamin D metabolism by a different means. In similar studies it was found that increases in calcium intake from 400 to $1,000 \mathrm{mg} / \mathrm{d}$ did not alter serum $1,25(\mathrm{OH})_{2} \mathrm{D}$ in two patients with sarcoidosis in whom serum values were abnormally ele-

Table II. Effects of Increased Calcium Intake on Vitamin D and Calcium Metabolism in Normal Subjects and Patients with Sarcoidosis

\begin{tabular}{|c|c|c|c|c|c|c|c|c|}
\hline Treatment & $\begin{array}{c}\text { Serum } \\
\mathrm{Ca}\end{array}$ & $\begin{array}{l}\text { Serum } \\
\mathrm{Ca}^{++}\end{array}$ & $\begin{array}{c}\text { Serum } \\
P\end{array}$ & $\begin{array}{c}\text { Serum } \\
25(\mathrm{OH}) \mathrm{D}\end{array}$ & $\begin{array}{l}\text { Serum } \\
\text { ACE }\end{array}$ & $\begin{array}{c}\text { Serum } \\
1,25(\mathrm{OH})_{2} \mathrm{D}\end{array}$ & $\begin{array}{c}\text { Urinary } \\
\mathrm{Ca}\end{array}$ & $\begin{array}{l}\text { Urinary } \\
P\end{array}$ \\
\hline & $m g / d l$ & $m g / d l$ & $m g / d l$ & $n g / m l$ & $U$ & $p g / m l$ & $m g / d$ & $m g / d$ \\
\hline \multicolumn{9}{|c|}{ Normal subjects (17) } \\
\hline Control & $9.0 \pm 0.1$ & $5.04 \pm 0.01$ & $4.1 \pm 0.1$ & $15 \pm 2$ & $23 \pm 2$ & $33 \pm 1$ & $134 \pm 14$ & $753 \pm 42$ \\
\hline Calcium & $9.0 \pm 0.1$ & $5.04 \pm 0.01$ & $4.3 \pm 0.1$ & $14 \pm 2$ & & $20 \pm 1$ & $193 \pm 20$ & $584 \pm 33$ \\
\hline$P$ value & NS & NS & $<0.01$ & NS & & $<0.001$ & $<0.001$ & $<0.01$ \\
\hline \multicolumn{9}{|l|}{ Patients (11) } \\
\hline Control & $9.2 \pm 0.1$ & $5.03 \pm 0.05$ & $3.9 \pm 0.2$ & $8 \pm 2^{*}$ & $38 \pm 5^{\ddagger}$ & $39 \pm 3^{*}$ & $159 \pm 26$ & $584 \pm 41^{*}$ \\
\hline Calcium & $9.2 \pm 0.1$ & $5.05 \pm 0.05$ & $3.9 \pm 0.2$ & $11 \pm 2$ & & $38 \pm 3^{\ddagger}$ & $238 \pm 29$ & $521 \pm 29$ \\
\hline$P$ value & NS & NS & NS & NS & & NS & $<0.001$ & NS \\
\hline
\end{tabular}

Results are given as mean $\pm \mathrm{SE}$.

${ }^{*} P<0.05$ vs. values in normal subjects.

${ }^{\ddagger} P<0.01$ vs. values in normal subjects. 


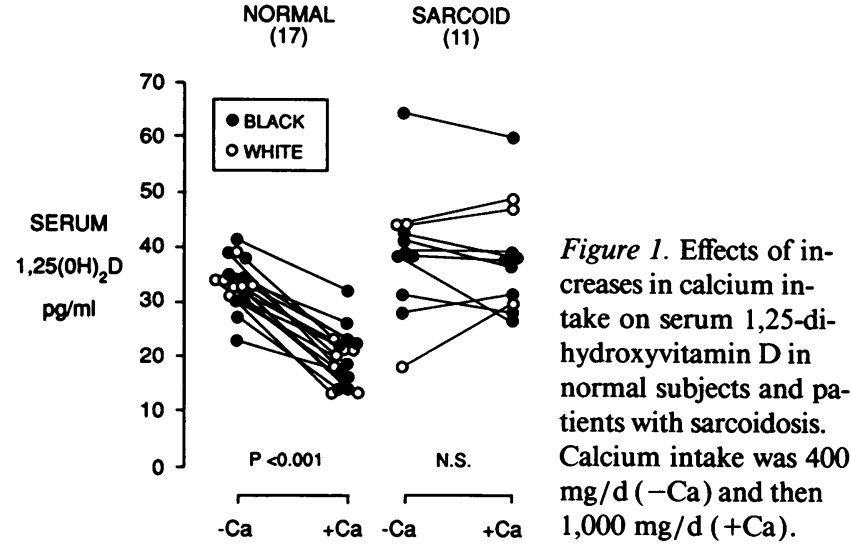

vated (22). Two of our patients eventually developed hypercalcemia, and hydroxychloroquine corrected the abnormal vitamin $\mathrm{D}$ and calcium metabolism in one of them (23). In view of the demonstration of abnormal regulation of vitamin D metabolism in our patients, it would appear that all normocalcemic patients with sarcoidosis are at risk for developing hypercalcemia and its consequences, renal stones, renal lithiasis, chronic renal failure, and even death $(13,24)$.

Serum ACE activity was abnormally elevated in only three of the patients. In contrast, the calcium suppression test was abnormal in all the patients. Thus, this test provides a better index of disease activity than serum ACE activity.

The reduction in urinary phosphate and the modest but significant increase in serum phosphate in the normal subjects as a consequence of increased calcium intake are attributed to inhibition of secretion of PTH and possibly to binding of calcium to phosphate in the intestine and prevention of its absorption.

In summary, our studies show that increases in calcium intake from 400 to $1,000 \mathrm{mg} / \mathrm{d}$ lowered serum $1,25(\mathrm{OH})_{2} \mathrm{D}$ in 17 normal subjects but not in 11 normocalcemic patients with sarcoidosis who had no history of abnormal calcium metabolism. The results indicate that regulation of circulating $1,25(\mathrm{OH})_{2} \mathrm{D}$ in these patients is abnormal and that they are at risk for developing hypercalcemia and hypercalciuria. In patients such as these, it is important that they be followed closely on a low calcium diet and that they be instructed to avoid vitamin D supplements and exposure to sunlight, especially in the summer.

\section{Acknowledgments}

Our research was supported in part by the Research Service of the Department of Veterans Affairs and by grants AR36066 and M01 RR01070 (General Clinical Research Center of the Medical University of South Carolina) from the U. S. Public Health Service.

\section{References}

1. Gallagher, J. C., B. L. Riggs, J. Eisman, A. Hamstra, S. B. Arnaud, and H. F. DeLuca. 1979. Intestinal calcium absorption and serum vitamin D metabolites in normal subjects and osteoporotic patients. Effect of age and dietary calcium. $J$. Clin. Invest. 64:729-736.

2. Adams, N. D., R. W. Gray, and J. Lemann. 1979. The effects of oral $\mathrm{CaCO}_{3}$ loading and dietary calcium deprivation on plasma 1,25-dihydroxyvitamin $\mathrm{D}$ concentrations in healthy adults. J. Clin. Endocrinol. \& Metab. 48:1008-1016.

3. Brumbaugh, P. F., and M. R. Haussler. 1974. $1 \alpha, 25$-Dihydroxycholecalciferol receptors in the intestine. J. Biol. Chem. 249:1251-1262.

4. Garabedian, M., M. F. Holick, H. F. DeLuca, and I. T. Boyle. 1972. Control of 25-hydroxycholecalciferol metabolism by the parathyroid glands. Proc. Natl. Acad. Sci. USA. 69:1673-1676.

5. Lambert, P. W., B. W. Hollis, N. H. Bell, and S. Epstein. 1980. Demonstration of a lack of change in serum $1 \alpha, 25$-dihydroxyvitamin $\mathrm{D}$ in response to parathyroid extract in pseudohypoparathyroidism. J. Clin. Invest. 66:782-791.

6. Hulter, H. N., B. P. Halloran, R. D. Toto, and J. C. Peterson. 1985. Longterm control of plasma calcitriol concentration in dogs and humans. Dominant role of plasma calcium concentration in experimental hyperparathyroidism. $J$. Clin. Invest. 76:695-702.

7. Gray, R. W., D. R. Wilz, A. E. Caldas, and J. Lemann. 1977. The importance of phosphate in regulating $1,25-(\mathrm{OH})_{2}$-vitamin $\mathrm{D}$ levels in humans: studies in healthy subjects, in calcium-stone formers and in patients with primary hyperparathyroidism. J. Clin. Endocrinol. \& Metab. 45:299-306.

8. Portale, A. A., B. P. Halloran, M. M. Murphy, and R. C. Morris, Jr. 1986. Oral intake of phosphorus can determine the serum concentration of 1,25-dihydroxyvitamin D by determining its production rate in humans. J. Clin. Invest. 77:7-12.

9. Hughes, M. R., D. J. Baylink, P. G. Jones, and M. R. Haussler. 1976. Radioligand receptor assay for 25 -hydroxyvitamin $D_{2} / D_{3}$. Application to hypervitaminosis D. J. Clin. Invest. 58:61-70.

10. Adams, J. S., O. P. Sharma, M. A. Gacad, and F. R. Singer. 1983. Metabolism of 25-hydroxyvitamin $\mathrm{D}_{3}$ by cultured pulmonary alveolar macrophages in sarcoidosis. J. Clin. Invest. 72:1856-1860.

11. Adams, J. S., and M. A. Gacad. 1985. Characterization of a $1 \alpha$-hydroxylation of vitamin $D_{3}$ sterols by cultured alveolar macrophages from patients with sarcoidosis. J. Exp. Med. 161:755-765.

12. Reichel, H., H. P. Koeffler, R. Barbers, and A. W. Norman. 1987. Regulation of 1,25 -dihydroxyvitamin $D_{3}$ production by cultured alveolar macrophages from normal human donors and from patients with pulmonary sarcoidosis. $J$. Clin. Endocrinol. \& Metab. 65:1201-1209.

13. Bell, N. H., P. H. Stern, E. Pantzer, T. K. Sinha, and H. F. DeLuca. 1979. Evidence that increased circulating $1 \alpha, 25$-dihydroxyvitamin $\mathrm{D}$ is the probable cause for abnormal calcium metabolism in sarcoidosis. J. Clin. Invest. 64:218225.

14. Stern, P. H., J. De Olazabal, and N. H. Bell. 1989. Evidence for abnormal regulation of circulating $1 \alpha, 25$-dihydroxyvitamin $\mathrm{D}$ in patients with sarcoidosis and normal calcium metabolism. J. Clin. Invest. 66:852-855.

15. DeRemee, R. A., and M. S. Rohrbach. 1978. Serum angiotensin-converting enzyme activity in evaluating the clinical course of sarcoidosis. Ann. Intern. Med. 84:272-276.

16. DeRemee, R. A., E. G. Lu f kin, and M. S. Rohrbach. 1985. Serum angiotensinconverting enzyme activity: its use in the evaluation and management of hypercalcemia associated with sarcoidosis. Arch. Intern. Med. 145:677-679.

17. Baginski, E. S., S. S. Marie, and B. Zak. 1973. Direct micro determination of calcium. Clin. Chim. Acta. 46:49-54.

18. Daly, J. A., and G. Ertinghausen. 1972. Direct method for determining inorganic phosphorus in serum. Clin. Chem. 18:263-267.

19. Belsey, R. E., H. F. DeLuca, and J. T. Potts, Jr. 1974. A rapid assay for 25-OH-vitamin $\mathrm{D}_{3}$ without preparative chromatography. J. Clin. Endocrinol. \& Metab. 38:1046-1051.

20. Reinhardt, T. A., R. L. Horst, J. W. Orf, and B. W. Hollis. 1984. A microassay for 1,25-dihydroxyvitamin $\mathrm{D}$ not requiring high performance liquid chromatography: application to clinical studies. J. Clin. Endocrinol. \& Metab. 58:91-98.

21. Bartels, H., and M. Bohmer. 1971. Eine mikromethode zur kreatinin bestimmung. Clin. Chim. Acta. 32:81-85.

22. Broadus, A. E., K. L. Insogna, R. Lang, A. F. Ellison, and B. E. Dreyer. 1984. Evidence of disordered control of 1,25-dihydroxyvitamin $\mathrm{D}$ production in absorptive hypercalciuria. $N$. Engl. J. Med. 311:73-80.

23. DeSimone, D. P., H. L. Brilliant, J. Basile, and N. H. Bell. 1989. Granulomatous infiltration of the talus and abnormal vitamin $D$ and calcium metabolism in a patient with sarcoidosis: successful treatment with hydroxychloroquine. $\mathrm{Am}$. J. Med. 87:694-696.

24. Bell, N. H., J. R. Gill, and F. C. Bartter. 1964. On the abnormal calcium absorption in sarcoidosis: evidence for increased sensitivity to vitamin D. Am. J. Med. 36:500-513. 